\title{
Mycoplasma cavipharyngis, a New Species Isolated from the Nasopharynx of Guinea-pigs
}

\author{
By AURIOL C. HILL \\ Medical Research Council Experimental Embryology and Teratology Unit, \\ Woodmansterne Road, Carshalton, Surrey SM5 4EF, UK
}

(Received 5 January 1984; revised 13 July 1984)

Two mycoplasma strains isolated from the nasopharynx of guinea-pigs in two separate colonies were biochemically and serologically identical, and distinct from 80 Mycoplasma and Acholeplasma spp. One of them, strain 117C (NCTC 11700), is designated the type strain of a new species Mycoplasma cavipharyngis.

\section{INTRODUCTION}

The four characterized mycoplasmas reported in guinea-pigs are Mycoplasma caviae, $M$. pulmonis, Acholeplasma granularum and A. laidlawii (Juhr \& Obi, 1970; Hill, 1971 a, 1974a, b). $M$. caviae is the only species which has not been isolated from other animals, and $M$. pulmonis and $A$. granularum are more common in rats, mice and pigs.

The isolation of further mycoplasma species from guinea-pigs was reported by Hill $(1971 b)$. Mycoplasma strains $117 \mathrm{C}$ and 22D were recovered from the nasopharynx of eight guinea-pigs in two animal colonies (Hill, 1974a). Strain 117C readily colonized the nasopharynx in mice after intranasal inoculation (A. C. Hill, unpublished observations).

\section{METHODS}

Mycoplasma strains. Strains 117C and 22D were isolated from the nasopharynx of guinea-pigs in separate animal colonies. There was no evidence of disease in these animals.

Mycoplasma species. Mycoplasma type cultures were obtained from the National Collection of Type Cultures, Colindale, UK, and Drs H. Atobe (University of Tokyo, Tokyo, Japan), M. F. Barile (National Institutes of Health, Bethesda, Md., USA), J. M. Bradbury (Liverpool University, Neston, UK), R. J. Fallon (Ruchill Hospital, Glasgow, UK), E. A. Freundt (University of Aarhus, Aarhus, Denmark), J. T. Heywood (National Communicable Disease Center, Atlanta, Ga., USA), F. T. W. Jordan (Liverpool University, Neston, UK), D. E. Jasper (University of California, Davis, Calif., USA), H. Kirchoff (Tierarztliche Hochschule, Hannover, FRG), R. H. Leach (PHLS Mycoplasma Reference Laboratory, Norwich, UK), G. Smith (Zoological Society of London, London, UK), D. Taylor-Robinson (Clinical Research Centre, Harrow, UK), and J. G. Tully (National Institutes of Health, Bethesda, Md., USA).

Medium and growth conditions. The basal culture medium was that described by Taylor-Robinson et al. (1968) and Hill (1971 a). The purified agar used in the solid medium was either Ionagar No. 2 (Oxoid) or 'Lab M' agar (Lab M, London, UK). Mycoplasmas were usually grown in basal liquid medium containing either $1 \%(\mathrm{w} / \mathrm{v})$ glucose, $\mathrm{pH} 7.8$ or $1 \%(\mathrm{w} / \mathrm{v})$ arginine, $\mathrm{pH} 7.3$ depending on their biochemical activity. Agar cultures were incubated at $35^{\circ} \mathrm{C}$, either in a humid chamber or under anaerobic conditions. Liquid cultures were stored at $-70^{\circ} \mathrm{C}$ in ampoules.

Growth requirements and characteristics. The isolates, strains $117 \mathrm{C}$ and 22D, were cloned by filtration through $450 \mathrm{~nm}$ filters, inoculation of the filtrate onto solid medium and inoculation of a single colony into broth. This process was repeated three times. One clone of each strain was studied.

Abbreviation: SPS, Sodium polyanetholesulphonate. 
The strains were subcultured onto solid medium and grown for one week under both aerobic and anaerobic (Gaspak) conditions at $35^{\circ} \mathrm{C}$. Inhibition of growth by methylene blue was investigated by adding $0.002^{\circ}$ \% $(\mathrm{w} / \mathrm{v})$ methylene blue to the basal solid medium. Lipolytic activity was tested by inoculating mycoplasmas onto basal medium enriched with $10 \%(\mathrm{v} / \mathrm{v})$ egg yolk emulsion (Fabricant \& Freundt, 1967). Plates were examined at 3, 7 and $14 \mathrm{~d}$.

Absence of reversion. The isolates were subcultured by five passages onto both solid and liquid media that contained no microbial inhibitors, and were incubated aerobically to see whether they reverted to a bacterial form.

Morphological studies. Mycoplasma colonies grown on agar were examined after 2, 7 and $14 \mathrm{~d}$ incubation. Some colonies were transferred to slides and stained with Giemsa stain (Klieneberger-Nobel, 1962; Fallon \& Whittlestone, 1969). Liquid cultures were observed under dark-field microscopy and organisms were also stained with Giemsa stain (Fallon \& Whittlestone, 1969). Organisms grown in broth were harvested by centrifugation and the cell pellet fixed at room temperature in glutaraldehyde $(2 \%, \mathrm{v} / \mathrm{v})$ for $2 \mathrm{~h}$ and post fixed in osmium tetroxide $(1 \%, w / v)$ for $1 \mathrm{~h}$. Thin sections were cut and stained with uranyl acetate and lead citrate (Venable \& Coggeshall, 1965 ), and examined by electron microscopy.

Filtration studies. Cultures ( $24 \mathrm{~h}$ incubation) were diluted 1 in 10 in liquid medium, and then volumes of diluted culture filtered through membrane filters (Millipore) with pore diameters of 220,300, 450,650 and $800 \mathrm{~nm}$. The number of c.f.u. $\mathrm{ml}^{-1}$ in the filtrate was determined and compared with that of the original unfiltered 1 in 10 culture dilution.

Sterol dependence. The mycoplasmas were seeded onto a serum-free solid medium supplemented with bovine serum albumin, glucose and palmitic acid (Razin \& Tully, 1970). Cholesterol, dissolved in Tween 80 (final aqueous concentration $0 \cdot 01 \%, \mathrm{v} / \mathrm{v})$, was added to give concentrations of $20,10,5$ and $1 \mu \mathrm{g} \mathrm{ml}^{-1}$. Plates containing no cholesterol were included (Edward \& Fitzgerald, 1951; Tully \& Razin, 1969; Razin \& Tully, 1970: Edward, 1971 ). Mycoplasmas were also subcultured onto the solid growth medium without serum.

The isolates were tested for sensitivity with discs containing $0.02 \mathrm{ml}$ of either a $1.5 \%(\mathrm{w} / \mathrm{v})$ ethanolic solution of digitonin (Sigma) or a $20 \%(\mathrm{w} / \mathrm{v})$ aqueous solution of sodium polyanetholesulphonate (SPS) (Koch-Light). The width of the zone of growth inhibition was measured (Freundt et al., 1973).

Biochemical activity. The isolates were examined for: carbohydrate metabolism; hydrolysis of aesculin, arginine and urea (Shepard \& Howard, 1970; Williams \& Wittler, 1971; Leach, 1976); reduction of methylene blue, resazurin, tetrazolium and tellurite; and phosphatase activity (Tully, 1965; Aluotto et al., 1970; Barber \& Fabricant, 1971).

Erythrocyte techniques. Haemolytic activity (Aluotto et al., 1970), and adsorption and agglutination of erythrocytes (Manchee \& Taylor-Robinson, 1968) were tested with fowl, guinea-pig, human and sheep cells.

Polyacrylamide gel electrophoresis. Electrophoresis was done as described by Razin \& Rottem (1967). M. californicum (ST-6) was compared with strain $117 \mathrm{C}$ because of the slight serological cross-reaction between them. Centrifuged cell suspensions were dried and $6 \mathrm{mg}$ dissolved in $0.6 \mathrm{ml}$ phenol/acetic acid/water $(2: 1: 0 \cdot 5$, by vol. $)$. The gels were loaded with $0.025 \mathrm{ml}$ and $0.05 \mathrm{ml}$ of the cell sample. After electrophoresis at room temperature for $3.5 \mathrm{~h}$ at a constant current of $5 \mathrm{~mA}$ per tube the gels were stained with $l_{0}^{\circ}(\mathrm{w} / \mathrm{v})$ naphthol blue black.

DNA base composition. DNA was extracted by the method of Kirby (1959), and the guanine-plus-cytosine (G+ C) content determined from its thermal denaturation temperature (Marmur \& Doty, 1962). DNA extracted from Clostridium perfringens and $M$. gallisepticum, which have known $\mathrm{G}+\mathrm{C}$ contents, were included as controls.

Serological studies. Antisera were prepared as described by Morton \& Roberts (1967) and Hill (1971 $a$ ). Three types of tests were done, each in duplicate : growth inhibition tests on sterile paper discs impregnated with antisera on a solid medium seeded with a mycoplasma culture (Clyde, 1964): metabolism inhibition tests in microtitre plates containing dilutions of antiserum, broth medium and a standard inoculum of mycoplasma broth culture (Purcell et al., 1966a, b; Taylor-Robinson et al., 1966; Hill, 1977); and an immunoperoxidase test on colonies grown on agar (Polak-Vogelzang et al., 1978). Strains $117 \mathrm{C}$ and 22D were reacted with antisera prepared against the species listed in the footnote to Table 2, and antiserum to strains 117C and 22D was tested with these species. Antisera to the two strains $117 \mathrm{C}$ and $22 \mathrm{D}$ were reacted with each other.

\section{RESULTS}

One to two weeks elapsed before colonial growth was visible on the initial isolation of strains $117 \mathrm{C}$ and 22D but subcultures formed colonies in 3 to $4 \mathrm{~d}$. These strains did not grow anaerobically. Colonies were small and granular (Fig. 1); typical 'fried egg' colonies were only seen after prolonged incubation. Growth characteristics are shown in Table 1. Neither of the isolates reverted to bacteria when subcultured onto medium without bacterial inhibitors. Growth was partially inhibited on methylene blue agar and helical forms were not seen.

No motility was noticed under dark-field microscopy. Liquid cultures stained with Giemsa stain were pleomorphic, and consisted of small coccoid units, sometimes in chains and 


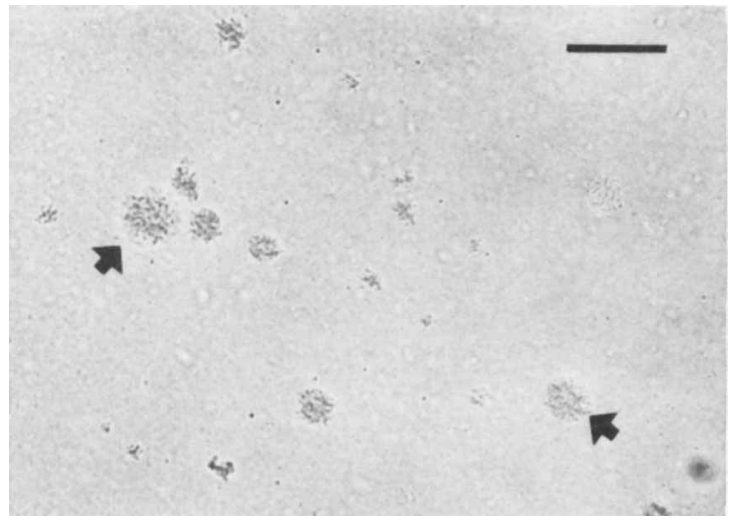

Fig. 1. Colonies of strain $117 \mathrm{C}$ grown aerobically for $4 \mathrm{~d}$ on an agar medium. Arrows indicate colonies. Bar marker, $50 \mu \mathrm{m}$.

Table 1. Colonial and biochemical characteristics of Mycoplasma strains $117 \mathrm{C}$ and 22D

Key: $+(-)$ Growth positive (film negative); - , negative; \pm , weak reaction; + , positive.

Test

Aerobic growth (film)

Anaerobic growth

Growth on methylene blue agar

Clearing on egg yolk agar

Film on egg yolk agar

Growth without serum

Aesculin hydrolysis

Arginine hydrolysis

Urease production

Glucose metabolism

Methylene blue reduction

Resazurin reduction

Tetrazolium reduction

Tellurite reduction

Casein digestion

Phosphatase production

$\begin{array}{cc}\text { Strain } & \text { Strain } \\ 117 \mathrm{C} & 22 \mathrm{D} \\ +(-) & +(-) \\ - & - \\ \pm & \pm \\ - & - \\ - & - \\ - & - \\ - & - \\ - & - \\ - & + \\ + & + \\ + & + \\ + & \pm \\ \pm & - \\ - & + \\ + & -\end{array}$

occasionally in rings. The organisms were typical of mycoplasmas when thin sections were examined by electron microscopy, and cells were bounded by a single unit membrane (Fig. 2).

Filtration of the mycoplasmas $\left(8 \times 10^{5} \mathrm{ml}^{-1}\right)$ showed that reduced numbers passed through membranes with $450 \mathrm{~nm}$ pore size $\left(9 \times 10^{2} \mathrm{ml}^{-1}\right)$ and none through the membrane with a pore size of $300 \mathrm{~nm}$.

The organisms required $5 \mu \mathrm{g}$ cholesterol $\mathrm{ml}^{-1}$ for growth. They were sensitive to digitonin and SPS with 7-12 $\mathrm{mm}$ and 5-8 $\mathrm{mm}$ zones of growth inhibition respectively.

Biochemical activity is shown in Table 1 . The isolates metabolized fructose, glucose, maltose, mannose, raffinose and sucrose, but not arabinose, arbutin, cellobiose, dulcitol, galactose, glycerol, inositol, lactose, mannitol, rhamnose, salicin, sorbitol, trehalose or xylose, and did not hydrolyse arginine. They lysed but did not agglutinate guinea-pig, human sheep or fowl erythrocytes. However, they were adsorbed by guinea-pig, human and sheep but not fowl erythrocytes.

Strains $117 \mathrm{C}$ and 22D gave a similar electrophoretic protein pattern. The protein pattern of strain $117 \mathrm{C}$ was distinct from those of $M$. caviae and $M$ californicum (Fig. 3). 


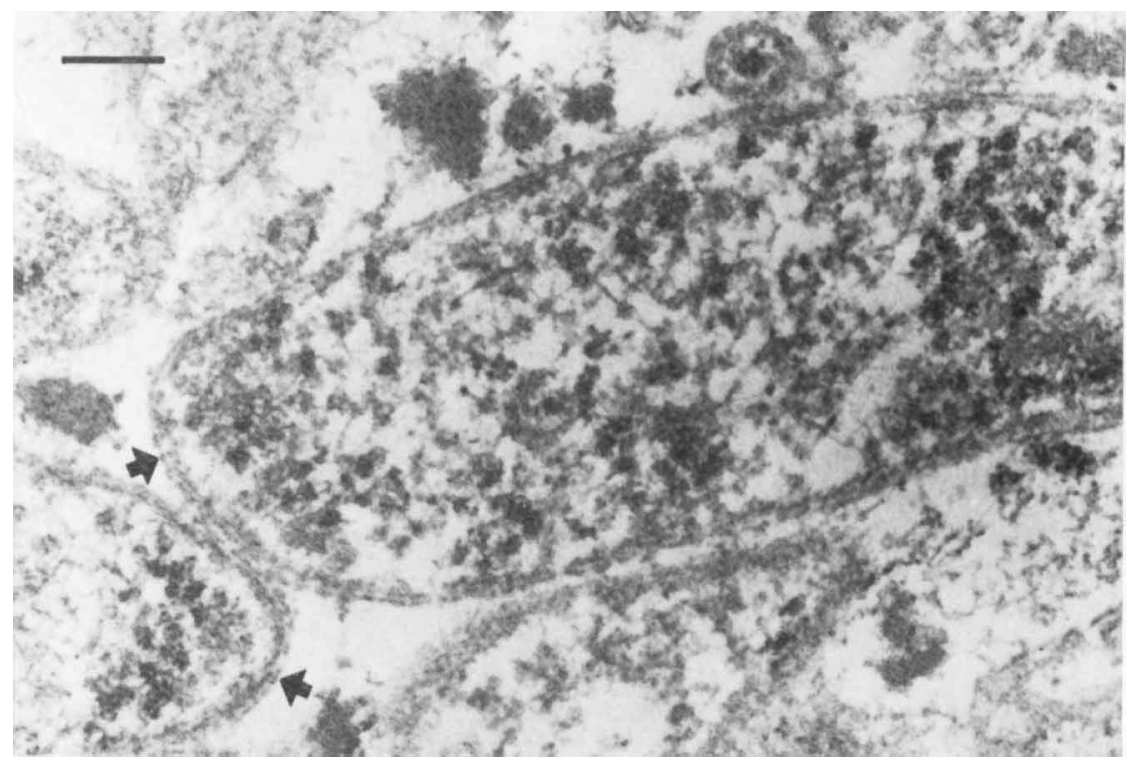

Fig. 2. Electron micrograph of thin section of Mycoplasma strain 117C stained with uranyl acetate and lead citrate. Arrows indicate membrane. Bar marker, $250 \mathrm{~nm}$.

(a)

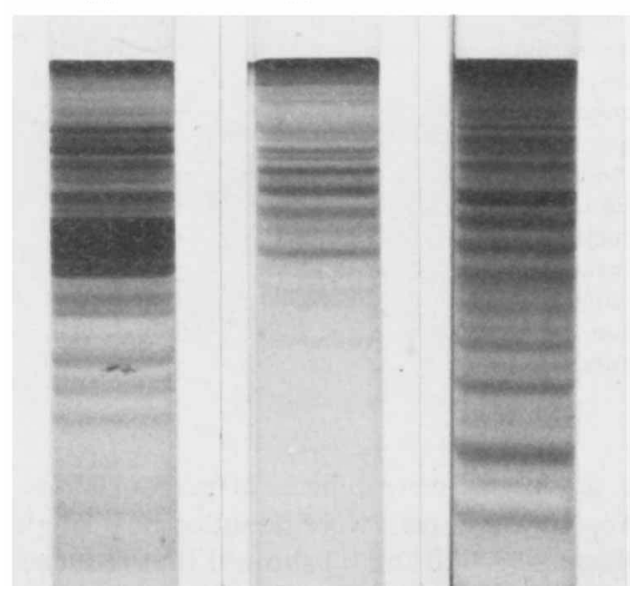

Fig. 3. Electrophoretic protein patterns of $M$. californicum (a), M. caviae (b) and strain $117 \mathrm{C}(c)$.

DNA was denatured at a midpoint temperature of $81.5^{\circ} \mathrm{C}$ (corrected for thermal expansion) over several tests. The $\mathrm{G}+\mathrm{C}$ content of $30 \%$ was evaluated by the equation $T_{m}=69 \cdot 3+0.41$ $(\mathrm{G}+\mathrm{C})$ (Marmur \& Doty, 1962), and fell within the range for Mycoplasma spp.

Serological techniques showed a high level of cross-reactions between the two strains (Table 2). No cross-reactions were detected with any of the species tested (see Table 2, footnote) except for a slight one-way reaction to $M$. californicum antiserum in the growth inhibition and metabolism inhibition tests (Table 2). 
Table 2. Serological reactions comparing strains $117 \mathrm{C}$ and $22 \mathrm{D}$ with $\mathrm{M}$. californicum (ST-6) and other named species

\begin{tabular}{|c|c|c|c|c|c|c|c|c|c|}
\hline \multirow[b]{3}{*}{ Antigen } & \multicolumn{3}{|c|}{$\begin{array}{l}\text { Growth inhibition } \\
\text { zone diam. (mm) }\end{array}$} & \multicolumn{3}{|c|}{$\begin{array}{c}\text { Reciprocal of } \\
\text { metabolism inhibition titre }\end{array}$} & \multicolumn{3}{|c|}{$\begin{array}{c}\text { Reciprocal of } \\
\text { immunoperoxidase titre }\end{array}$} \\
\hline & \multicolumn{3}{|c|}{ Antiserum: } & \multicolumn{3}{|c|}{ Antiserum: } & \multicolumn{3}{|c|}{ Antiserum: } \\
\hline & $117 \mathrm{C}$ & $22 \mathrm{D}$ & M. californicum & $117 \mathrm{C}$ & $22 \mathrm{D}$ & M. californicum & $117 \mathrm{C}$ & 22D & M. californicum \\
\hline $117 \mathrm{C}$ & 3 & 3 & 0 & 32000 & 32000 & 32 & 8000 & 8000 & $<60$ \\
\hline $22 \mathrm{D}$ & 3 & 3 & $\mathbf{R} \dagger$ & 32000 & 32000 & 64 & 8000 & 8000 & $<60$ \\
\hline M. californicum & 0 & 0 & 2 & $<16$ & $<16$ & 4196 & $<60$ & $<60$ & 4800 \\
\hline All other strains* & 0 & 0 & & $<32$ & $<32$ & & $<60$ & $<60$ & \\
\hline
\end{tabular}

* M. agalactiae (PG2), M. alkalescens (PG51), M. alvi(Ilsley), M. anatis (1340), M. arginini (G230), M. arthritidis (PG6), M. bovigenitalium (PG11), M. bovirhinis (PG43), M. bovis (PG45), M. bovoculi (M165/69), M. buccale (CH20247), M. californicum (ST-6), M. canadense (275C), M. canis (PG14), M. capricolum (California kid), M. cariae (G122), M. citelli (RG-2C), M. collis (58B), M. columbinosale (694), M. columbinum (MMP1), M. columborale (MMP4), M. conjunctivae (HRC581), M. cricetuli (CH), M. cynos (H831), M. dispar (462/2), M. edwardii (PG24), $M$. equigenitalium (T37), M. equirhinis (M432/72), M. fastidiosum (4822), M. faucium (DC333), M. feliminutum (Ben), M. felis (CO), M. fermentans (PG18), M. flocculare (MS42), M. gallinaceum(DO), M. gallinarum (PG16), $M$. gallisepticum (PG31), M. gallopavonis (WR1), M. gateae (CS), M. genitalium (G-37), M. hominis (PG 21), M. hyopneumoniae (J), M. hyorhinis (BTS7), M. hyosynotiae (S16), M. iners (PG30), M. iowae (695), M. lipofaciens (R171), M. lipophilum (MaBY), M. maculosum (PG15), M. meleagridis (17529), M. moatsii (MK 405), M. molare (H542), $M$. muris (RIII), M. mustelae (MX9), M. mycoides subsp. capri (PG3), M. mycoides subsp. mycoides (PG1), M. neurolyticum (Type A), M. opalescens (MH5408), M. orale (CH-19299), M. ovipneumoniae (Y98), M. pneumoniae (FH), M. primatum (HRC292), M. pullorum (CKK), M. pulmonis (PG34(ASH)), M. putrefaciens (KS-1), M. salivarium (PG20), M. spumans (PG13), M. sualvi (Mayfield strain (Clone B)), M. subdolum (TB), M. synoviae (WVU I853), M. verecundum (107), A. axanthum (S743), A. equifetale (N93), A. ganularum (BTS39), A. hippikon (C1), A. laidlawii (PG8), A. modicum (PG49), A. morum (72-043), A. oculi (19L), A. parvum (H23M).

$\uparrow$ Reduced numbers.

\section{DISCUSSION}

Strains $117 \mathrm{C}$ and 22D exhibited strong serological cross-reactions and had similar characteristics, and so they belong to the same species. This species belongs to the class Mollicutes as it is pleomorphic, has no cell wall and is bounded by a membrane. The lack of reversion when subcultured onto medium without bacterial inhibitors eliminates the possibility that the two strains may represent bacterial L-forms. This species passed through $450 \mathrm{~nm}$ membrane filters and grew on an artificial medium.

This species is in the family Mycoplasmataceae because of its dependence upon sterol for growth, sensitivity to digitonin and SPS, and absence of helical forms when examined by darkfield microscopy. It belongs to the genus Mycoplasma because urease is not produced. The $\mathrm{G}+$ $\mathrm{C}$ content is within the known range for Mycoplasma spp.

Strains $117 \mathrm{C}$ and 22D showed no serological cross-reactions with any of the named species listed in Table 2 (footnote) (except $M$. californicum) and therefore belong to a new species. The slight reaction to $M$. californicum was not shown in the immunoperoxidase test, and the biochemical reactions, growth characteristics and protein patterns of the two species are distinct.

It is suggested that the species be named Mycoplasma cavipharyngis, type strain $117 \mathrm{C}$, NCTC 11700.

\section{Mycoplasma cavipharyngis sp. nov.}

cavipharyngis - pharynx of guinea-pig.

Habitat. Upper respiratory tract of guinea-pig.

Morphology. Pleomorphic cells bounded by a single unit membrane. Colonies on agar small and granular.

DNA base composition. $30 \% \mathrm{G}+\mathrm{C}$ content.

Growth characteristics. Aerobe. Requires sterol for growth. Inhibition by digitonin and sodium polyanetholesulphonate (SPS).

Metabolic characteristics. Metabolizes glucose. Arginine and urea are not hydrolysed. 
I would like to thank Dr C. Tram, Pasteur Institute, Paris, for taking the electron micrographs and $\mathrm{Mr}$ R. Brooks, MRC Laboratories, Carshalton, for the other photographs.

\section{REFERENCES}

Alluotto, B. B., Wittler, R. G., Williams, C. O. \& FABER, J. E. (1970). Standardized bacteriologic techniques for the characterization of Mycoplasma species. International Journal of Systematic Bacteriology 20, 35-58.

BARBER, T. L. \& FABRICANT, J. (1971). Identification of Mycoplasmatales: characterization procedures. Applied Microbiology 21, 600-605.

CLYDE, W. A. JR (1964). Mycoplasma species identification based upon growth inhibition by specific antisera. Journal of Immunology 92, 958-965.

EDWARD, D. G. FF. (1971). Determination of sterol requirement for Mycoplasmatales. Journal of General Microbiology 69, 205-210.

Edward, D. G. FF. \& Fitzgerald, W. A. (1951). Cholesterol in the growth of organisms of the pleuropneumonia group. Journal of General Microbiology 5, 576-586.

Fabricant, J. \& Freund, E. A. (1967). Importance of extension and standardization of laboratory tests for the identification and classification of mycoplasma. Annals of the New York Academy of Sciences 143, 5058.

Fallon, R. J. \& Whittlestone, P. (1969). Isolation, cultivation and maintenance of mycoplasmas. Methods in Microbiology 3B, p. 253.

Freundt, E. A., ANdrews, B. E., ERno, H., Kunze, M. \& BLACK, F. T. (1973). The sensitivity of mycoplasmatales to sodium-polyanethol sulfonate and digitonin. Zentralblatt für Bakteriologie I. Abt. Originale $A$ 225, 104-112.

Hill, A. C. (1971 a). Mycoplasma caviae, a new species. Journal of General Microbiology 65, 109-113.

Hill, A. $(1971 b)$. The isolation of two further species of mycoplasma from guinea-pigs. Veterinary Record 83, 225.

Hill, A. C. $(1974 a)$. Mycoplasmas of small animal hosts. In Les Mycoplasmes/Mycoplasmas (Colloques, Institut National de la Santé et de la Recherche Médicale vol. 33), pp. 311-316. Edited by J. M. Bove \& J. F. Duplan. Paris: INSRM.

Hill, A. $(1974 b)$. Isolation of Acholeplasma laidlawii from guinea-pigs. Veterinary Record 94, 385.

Hill, A. C. (1977). The metabolic inhibition test for mycoplasmas based on phosphatase production. Journal of Hygiene 79, 391-393.

JUHR, N. C. \& OBI, S. (1970). Uterusinfektionen beim Meerschweinchen. Zeitschrift für Versuchstierkunde 12, 383-387.

KIRBY, K. S. (1959). The preparation of deoxyribonucleic acids by the $p$-aminosalicylate-phenol method. Biochimica et hiophysica acta 36, 391-393.

KLIENEBERGER-Nobel, E. (1962). Morphology of pleuropneumonia-like organisms. In Pleuropneumonia-like Organisms ( PPLO) Mycoplasmataceae, pp. 23-56. Edited by E. Klieneberger-Nobel. London \& New York: Academic Press.

LEACH, R. H. (1976). The inhibitory effect of arginine on growth of some mycoplasmas. Journal of Applied Bacteriology 41, 259-264.

Manchee, R. J. \& TAYlor-Robinson, D. (1968).
Haemadsorption and haemagglutination by mycoplasmas. Journal of General Microbiology 50, 465478.

Marmur, J. \& Doty, P. (1962). Determination of the base composition of deoxyribonucleic acid from its thermal denaturation temperature. Journal of Molecular Biology 5, 109-118.

Morton, H. E. \& Roberts, R. J. (1967). Production of anti-mycoplasma (PPLO) antibodies in rabbits. Proceedings of the Society for Experimental Biology and Medicine 125, 538-543.

Polak-Vogelzang, A. A., Hagenaars, R. \& Nagel, S. (1978). Evaluation of an indirect immunoperoxidase test for identification of Acholeplasma and Mycoplasma. Journal of General Microbiology 106. 241-249.

Purcell, R. H., Taylor-Robinson, D., Wong, D. C. \& Chanock, R. M. (1966a). A color test for the measurement of antibody to the non-acid-forming human mycoplasma species. American Journal of Epidemiology 84, 51-66.

Purcell, R. H., Taylor-Robinson, D., Wong, D. \& Chanock, R. M. $(1966 b)$. Color test for the measurement of antibody to $\mathrm{T}$-strain mycoplasmas. Journal of Bacteriology 92, 6-12.

RAZIN, S. \& ROTTEM, S. (1967). Identification of mycoplasma and other micro-organisms by polyacrylamide-gel electrophoresis of cell proteins. Journal of Bacteriology 94, 1807-1810.

Razin, S. \& Tully, J. G. (1970). Cholesterol requirement of mycoplasmas. Journal of Bacteriology 102. 306-310.

ShePARD, M. C. \& Howard, D. R. (1970). Identification of ' $T$ ' mycoplasmas in primary agar cultures by means of a direct test for urease. Annals of the New York Academy of Sciences 174, 809-819.

Taylor-Robinson, D., Purcell, R. H., Wong, D. C. \& CHANOCK, R. M. (1966). A colour test for the measurement of antibody to certain mycoplasma species based upon the inhibition of acid production. Journal of Hygiene 64, 91-104.

TAYloR-Robinson, D., Williams, M. H. \& HaIG, D. D. (1968). The isolation and comparative biological and physical characteristics of T-mycoplasmas of cattle. Journal of General Microbiology 54 , 33-46.

TULLY, J. G. (1965). Biochemical, morphological and serological characterization of mycoplasma of murine origin. Journal of Infectious Diseases 115 , 171-185.

Tully, J. G. \& RaZIN, S. (1969). Characteristics of a new sterol non-requiring mycoplasma. Journal of Bacteriology 98, 970-978.

Venable, J. H. \& Coggeshall, R. (1965). A simplified lead citrate stain for use in electron microscopy. Journal of Cell Biology 25, 407.

Williams, C. O. \& Wittler, R. G. (1971). Hydrolysis of aesculin and phosphatase production by members of the order Mycoplasmatales which do not require sterol. International of Journal of Systematic Bacteriology 21, 73-77. 